International Journal of Electrical Engineering and Technology (IJEET)

Volume 11, Issue 4, June 2020, pp. 8-21, Article ID: IJEET_11_04_002

Available online at https://iaeme.com/Home/issue/IJEET? Volume $=11 \&$ Issue $=4$

ISSN Print: 0976-6545 and ISSN Online: 0976-6553

DOI: https://doi.org/10.34218/IJEET.11.4.2020.002

\title{
DEVELOPMENT OF HYSTERESIS CURRENT CONTROLLER FOR POWER QUALITY ENHANCEMENT IN GRID CONNECTED PV SYSTEM
}

\author{
Dr. J Preetha Roselyn
}

Associate Professor, SRM Institute of Science and Technology, Chennai, India

Devraj Sen

Final Year (B-Tech), SRM Institute of Science and Technology, Chennai, India

\section{Pratyaksha Lal}

Final Year (B-Tech), SRM Institute of Science and Technology, Chennai, India

\section{Nayanika Purkayastha}

Final Year (B-Tech), SRM Institute of Science and Technology, Chennai, India

\section{Nithya}

Assistant Professor, SRM Institute of Science and Technology, Chennai, India

\begin{abstract}
The integration of distributed generation like solar and wind are increasing nowadays due to fossil fuel reduction and increased carbon emission. Many integration issues arise of connecting Solar PV to the grid out of which power quality is the important factor. Higher PV injection causes undesirable technical impacts on the distribution networks which leads to power quality issues. This paper studies the impact of $P V$ on the power quality of the utility grid with different levels of penetration of solar energy into the grid. The power quality of the grid is studied using the Total harmonic distortion (THD) by performing Fast Fourier Transform (FFT) analysis. This paper deals with the development of controllers for boost converter and grid tied inverters which minimizes the harmonics due to solar PV system and power converters in grid connected PV system. The Maximum Power Point Tracking (MPPT) for boost converter and Hysteresis current control (HCC) for inverter has been designed and implemented in grid connected PV system. The hysteresis current controller for the inverter has been specifically designed to reduce the THD of the system meeting IEEE519_1992 regulations. The simulation model of the grid connected PV system has been designed in MATLAB $2018 b$ version. The comparison studies are carried out in the PV system with and without hysteresis current controller, after which it can be
\end{abstract}


Development of Hysteresis Current Controller for Power Quality Enhancement in Grid Connected PV System

concluded that, after the incorporation of the hysteresis current controller, the performance of the system is better in terms of power quality.

Key words: Grid connected PV system, Hysteresis current controller, Maximum power point tracking, Total harmonic distortion.

Cite this Article: Dr. J Preetha Roselyn, Devraj Sen, Pratyaksha Lal, Nayanika Purkayastha and C Nithya, Development of Hysteresis Current Controller for Power Quality Enhancement in Grid Connected PV System, International Journal of Electrical Engineering and Technology, 11(4), 2020, pp. 8-21.

https://iaeme.com/Home/issue/IJEET?Volume $=11 \&$ Issue $=4$

\section{INTRODUCTION}

Solar power is one of the most readily available forms of renewable and clean energy source. The Indian subcontinent is the recipient of about $200 \mathrm{MW} / \mathrm{km}$ square of solar energy. This energy is spread throughout an expanse of 3.827 million-km square which amounts to 657.4 million MW per year. India receives about 2,300-3,200 hours of daylight per year thus there is very high scope for clean energy generation via solar power plants. The solar installed capacity reached $34.404 \mathrm{GW}$ according to the latest news within the Indian subcontinent. The statistics also show that India has the lowest capital cost for every mega- Watt for setting up of solar power plants. The extraction of power from renewable energy resources involves several power conversions stages. The conversion stages lead to distortions in the performance parameters that may be harmful for the power electronic components.

Shiva et al [1] gives a description of the power quality scenario of the entire country and how it is very important to integrate renewable energy to the existing grid to curtail the need for the ever-increasing population of the country. It gives a clear idea of the difficulties and issues faced by the integration of solar power to the grid system and suggests a control scheme using shunt active power filters and PI controller to improve the power quality of the system. Pekik et al [2] proposes a hysteresis current control scheme for single phase bridge inverters. The proposed scheme allows equal switching frequency among the various switching power devices. The paper also proposes the modification of the hysteresis doubleband which helps in reduction of harmonics of the system and increasing the quality of power.

Raja et al [3] provides a study of a solar photovoltaic system connected with grid under both $\mathrm{HCC}$ (hysteresis current control) and $\mathrm{HVC}$ (hysteresis voltage control) to reduce the harmonics in the system. Raju et al [4] presents a concept using reactive power compensation and SAPF(Shunt Active Power Filter).This method uses fourier block for reference current generation with the help of advanced adaptive $\mathrm{HB}$ (Hysteresis Band) current controller which helps in tracking the reference current.

Chinmay et al [5] uses a current control technique for grid integrated half bridge inverter. The simulation has been carried out in PSIM software using Hysteresis Band current control. Devaraj et al [6] compares the hysteresis voltage control and hysteresis current control and concludes that how both the controllers are effective in their own way. Devaraj et al [7] explain the design of boost converter in Stand-alone system in an elaborate manner. Pandey [8] uses the Clarke transform and elaborates how it is advantageous for a 3-phase system.

Dash R et al [9] presents a freshly developed robust control system forconcepts inclusing Microgrid and Smart grid. S Pradhan et al[10] shows a grid integrated pv system having the control algorithm DNLMS( Decorrelation Normalized Least Mean Square) which improves the system performance under conditions which are unfavourable. 
Nelson A. Patel et al [11] proposes a Hysteresis Current control algorithm for both AC and DC converters. A.Arias et al [12] presents a new method for hysteresis band current control which has been verified experimentally and is based on second input current error derivatives for the choice of zero voltage vectors. Renukadevi $\mathrm{V}$ et al[13] provides a dynamic model for PV Generation system. Simulink model has been designed in MATLAB and the results have been provided.

\section{STRUCTURE OF GRID- TIED PV SYSTEM}

The system discussed is a grid connected PV system. In the system there are following components: PV array, Boost converter with MPPT control, Inverter with Hysteresis Current Controller (HCC), Utility grid, Linear and non-linear loads and active filters. The schematic of the grid connected PV system is shown in figure 1.The PV module is connected to the converter (boost) which increases the voltage of PV to higher level. The switching of converter is done by MPPT algorithm which gives a range of duty cycle and extract the maximum power from the PV module irrespective of the factor that whatever condition the PV module falls under. The boost converter output is fed to the Inverter which converters DC to AC power and makes it suitable for feeding to the grid. The three-phase inverter's switching is controller using HCC. The HCC compares the feedback current extracted from the grid side and the generated reference current and develops a band width. The switching of the converter is such that the current which is being fed to grid is limited within the bandwidth of hysteresis controller, also known as Hysteresis Band, thus, current harmonics are reduced.

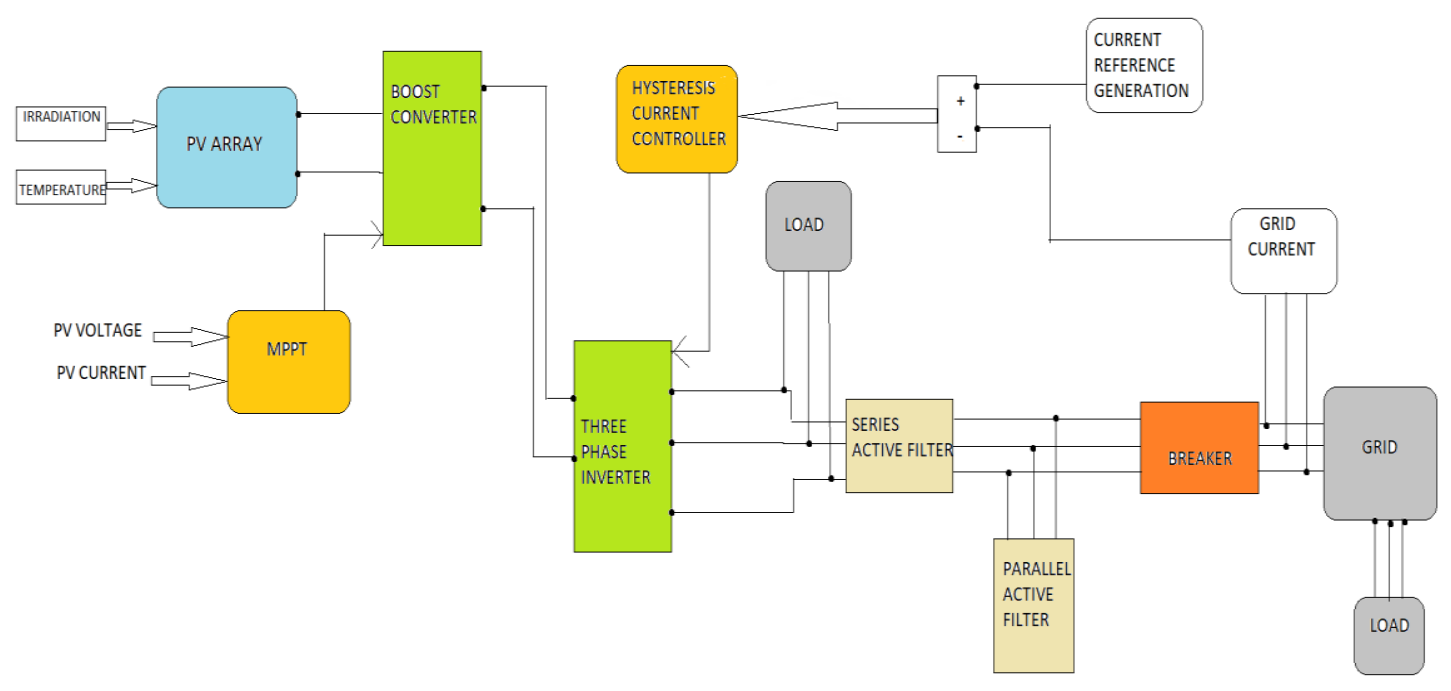

Figure 1 Schematic diagram for Grid-tied Solar PV system

\section{MODELING OF GRID CONNECTED PV SYSTEM}

The modeling of the grid connected PV system for all the components is designed and is provided below:

\subsection{PV Array Modeling}

The equivalent circuit of solar PV cell is shown in figure 2 and the corresponding PV and IV characteristics is shown in figure 3. 
Development of Hysteresis Current Controller for Power Quality Enhancement in Grid Connected PV System

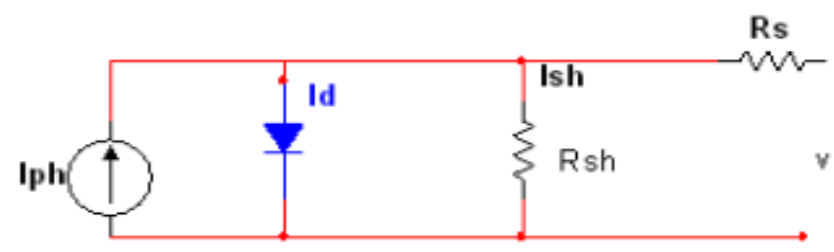

Figure 2. Equivalent of solar cell

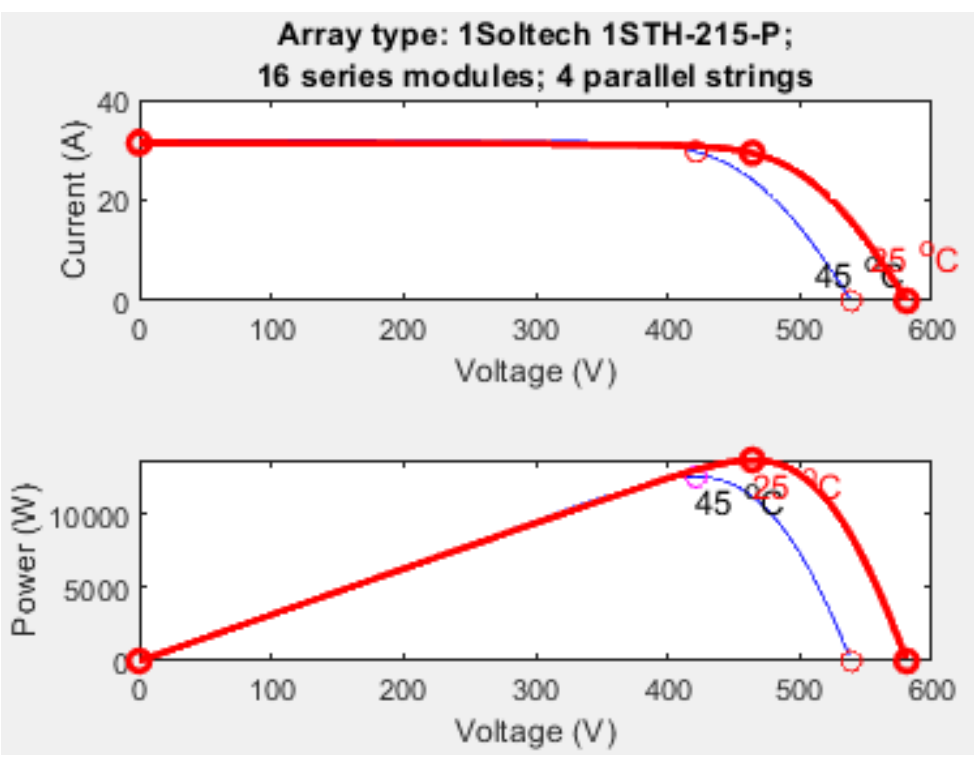

Figure 3 PV cell characteristic curve

\subsection{Boost Converter Model}

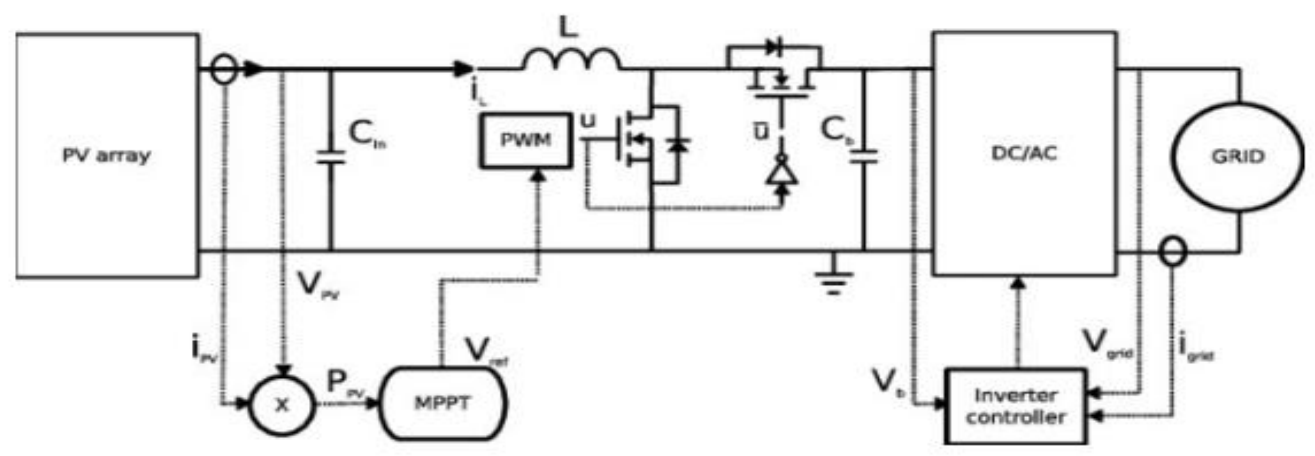

Figure 4 DC-DC boost converter

The boost converter is connected in between PV panel and Inverter. A capacitor is always given after PV panel when it is connected with a grid system since it reduces the ripple current. The inductor and capacitor are designed as follows:

Duty cycle, $D=1-\left(\frac{\text { Vout }}{\text { Vin }}\right)$ 


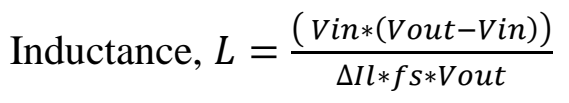

$\Delta I l=(0.2$ to 0.4$) * I o u t *\left(\frac{\text { Vout }}{\text { Vin }}\right)$

Capacitance, $C=\frac{(\text { Iout } * D)}{f S * \Delta V o u t}$

Where,

Vin = Input Voltage

Vout $=$ Desired Output voltage

$f s=$ Switching frequency

$\Delta I l=$ Change in ripple current

Iout $=$ Output current / boost current

$C=$ Capacitor

$D=$ Duty cycle

\subsection{Three Phase Voltage Source Inverter (VSI) Model}

Inverter converters the DC power obtained from the boost converter to AC power. Three phase inverter used in the system uses six MOSFET switches. The MOSFET's gate pulses are provided by the hysteresis controller, which controls the switching of the inverter switches such that distortions in output $\mathrm{AC}$ waveform is reduced.

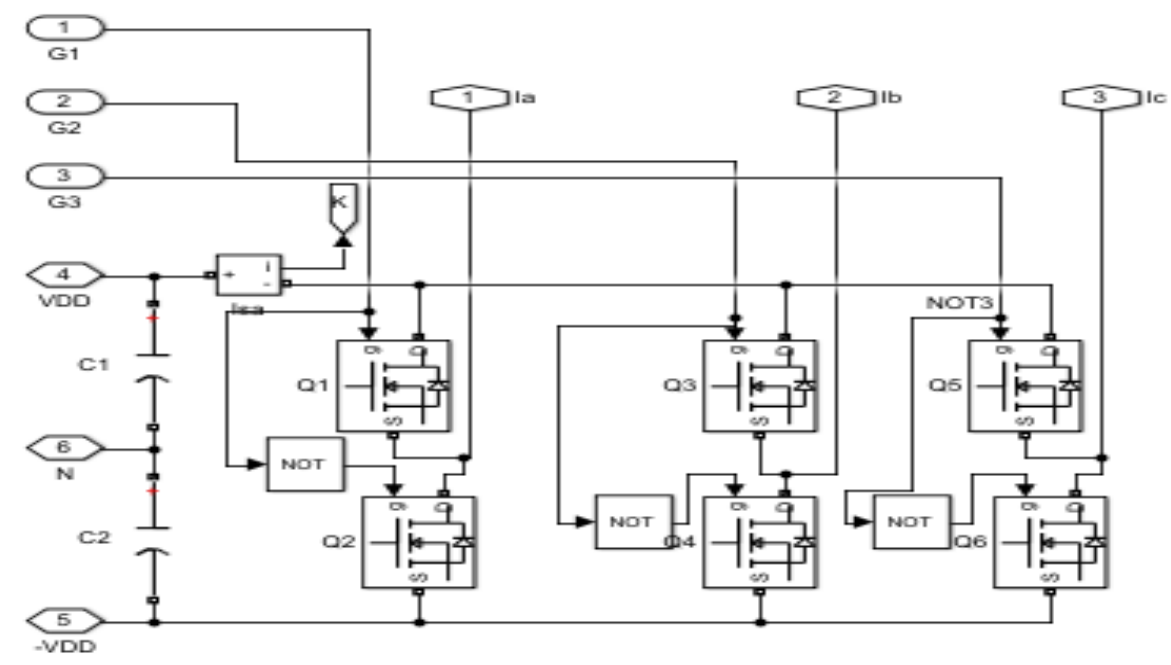

Figure 5 Three phase VSI

Referring figure 5, VDD, -VDD of the inverter terminals represents the output terminals of the boost converter. G1, G2, G3 are the gate pulses obtained from the inverter controller in this case hysteresis current controller. The upper switches Q1, Q3, Q5 are supplied with the gate pulses and the lower switches Q2, Q4, Q6 are supplied by NOT of the gate pulses. Sequential switching on and off of the inverter switches with the help of inverter control insures distortion less and production of pure sinusoidal AC waveform. 
Development of Hysteresis Current Controller for Power Quality Enhancement in Grid Connected PV System

\subsection{Design of Filter}

Two filters are used before feeding power to grid. One series active filter is used and one parallel active filter is used. The series active filter injects voltage which is produced in series with the supply. It manages or compensates the voltage sags and swells on the grid and the load side. This enhances the power quality. RL filter has been used in the model for series filter. The parallel active filter is used for reactive power compensation for nonlinear loads of the system. It provides reduction of harmonics in current. RC filter is used for parallel active filter.

$$
\begin{aligned}
& \mathrm{RL}=1.5 e^{-3} \text {. Pbase } \\
& \mathrm{L}=\frac{0.15 * \text { Pbase }}{2 * \text { pi*f }}
\end{aligned}
$$

Where $\mathrm{P}_{\text {base }}=$ Vbase $^{2} / \mathrm{P}$

$\mathrm{V}_{\text {base }}$ is the base value of the voltage for which the grid is designed.

$$
\begin{aligned}
& \mathrm{Qc}=0.1 \times \mathrm{P} \\
& \mathrm{Pc}=\frac{Q c}{50}
\end{aligned}
$$

Where $\mathrm{P}$ is the real power of the system in Watt.

\section{DESIGN OF CONTROLLER}

\subsection{MPPT Controller (Maximum Power Point Tracker)}

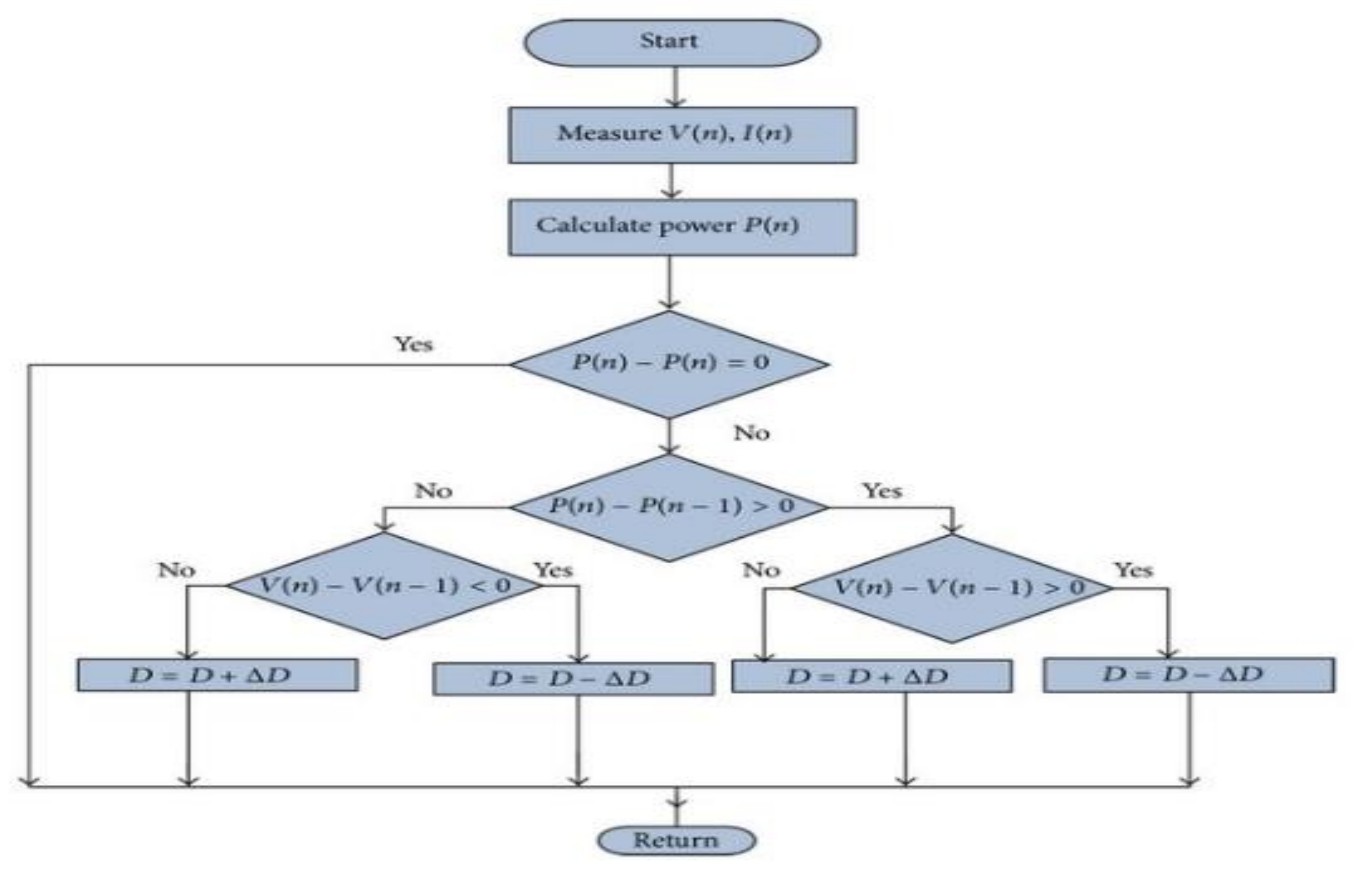

Figure 6 FLOWCHART of P\&O 
MPPT checks what type of PV module is given and check it's characteristics. From PV curve of the module, it tries to gain the MPP of the curve by substituting $\mathrm{dP} / \mathrm{dV}=0$. By solving the derivative we get the maximum power and maximum voltage of the curve. MPPT is given a range of duty cycle which helps to set the output voltage of the converter as per whatever reference value is given. There are several algorithms for achieving the maximum power of the PV system. The Perturb and Observe algorithm has been implemented in this paper.

This algorithm measures the V and I of the PV module from checking the characteristics. From PV curve of the module, it tries to gain the MPP of the curve by substituting $\mathrm{dP} / \mathrm{dV}=0$. It calculates the PV power by multiplying voltage and current. It compares the present and previous value of the power and checks whether it is greater than zero. The same process is followed for the voltage. After the voltage is set, the duty cycle is calculated which is fed to the switch of the converter.

\subsection{Design of Hysteresis Controller}

Hysteresis Current Controller compares the feedback current, the current being fed to the grid, with the generated reference current. The output of the comparison is fed to a relay defining the Upper Hysteresis Bound (UHB) and Lower Hysteresis Bound (LHB) of the hysteresis band. The controller makes the feedback current follow the reference current waveform. The output of the relay is fed to the gate terminal of the inverter switches. The HCC generates gating or switching pulses.

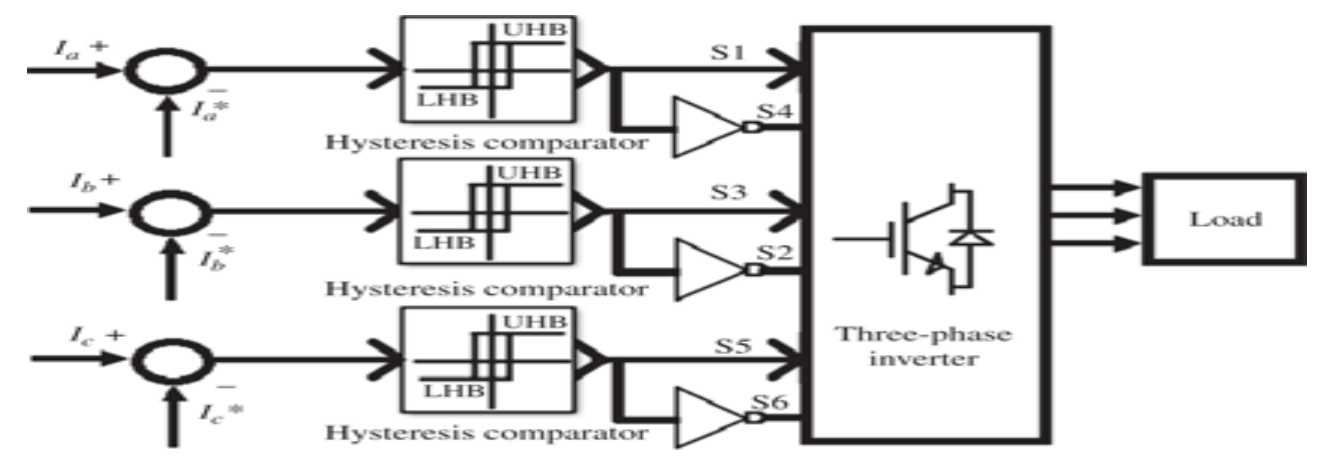

Figure 7 Hysteresis Current Controller

When the current error crosses or touches the upper limit, a voltage is applied less than 0 (or negative voltage) by the VSI to the grid. This results to decrease in current at the grid side. When the current error crosses or touches the lower limit, a voltage is applied greater than 0 (positive voltage) leading to the grid side and this results in increase in current at the grid side. For three phases, three current controllers are used which operate independently. Current ramps up and down in the grid which is shown in the figure 8 . The current reference extraction is the proposed algorithm used in HCC and Load balancing is applied on the development of the Hysteresis controller for better real power injection into the utility grid by the PV system. 
Development of Hysteresis Current Controller for Power Quality Enhancement in Grid Connected PV System

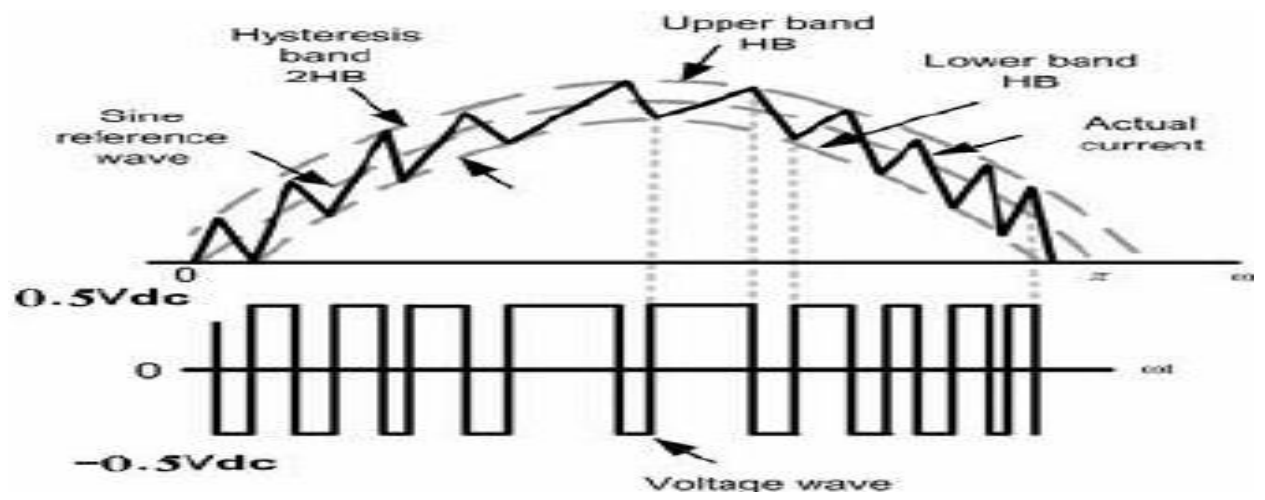

Figure 8 Hysteresis Band (HB)

Table 1 Inverter Switching Logic based on HB

\begin{tabular}{|c|c|}
\hline Status of the comparator & Status of the switch \\
\hline$>=$ Upper HB & ON - Upper Leg \\
& OFF- Lower Leg \\
\hline$>=$ Lower HB & OFF - Upper Leg \\
& ON- Lower Leg \\
\hline
\end{tabular}

\subsubsection{Current Reference Extraction}

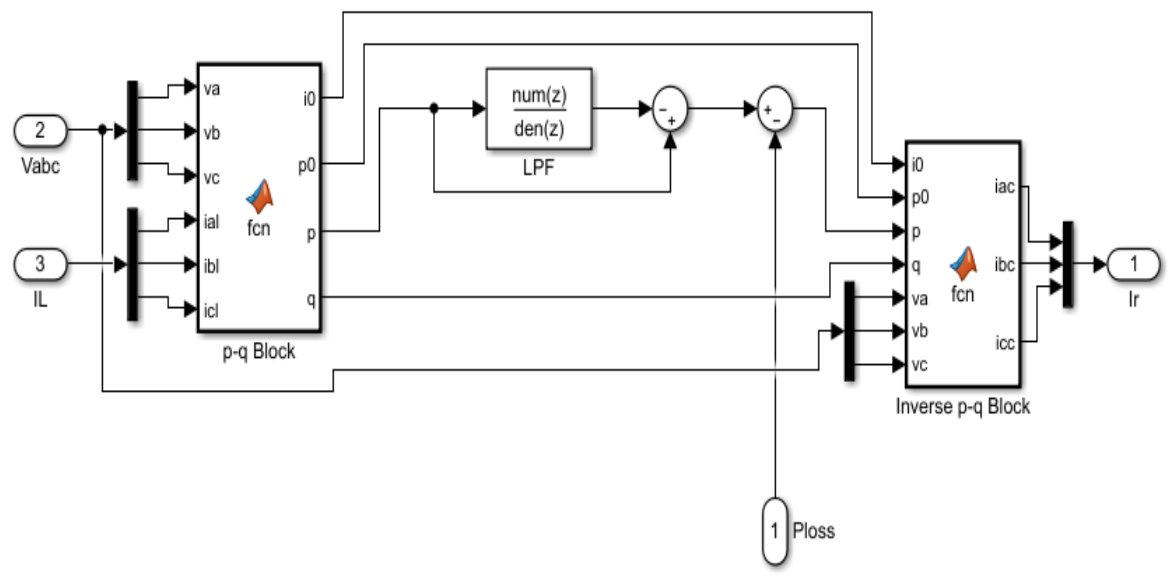

Figure 9 Simulink of Current Reference Extraction

The input voltage of VSI is compared with a voltage (reference) and injected to the Proportional Integral controller. PI controller is used because it is useful to obtain zero steady state error. The output of the PI controller is fed to the current compensating block. Compensation current block is used to generate reference current. It is a very important part in the hysteresis control method. It is a time domain method and is less complicated than frequency domain method. The $\mathrm{p}-\mathrm{q}$ conversion to $\alpha \beta$ frame is known as the Clarke Transformation. It transforms the "abc" (3-phase) voltage and current into $\alpha \beta$ stationary reference frame. After performing Clarke's transformation we apply a Low Pass Filter (LPF) to cancel out all the high frequency disturbances, and then again perform an Inverse Clarke's transformation. Inverse Clarke's Transformation is where we get the compensated three phases again. The compensated current is the reference current for the hysteresis controller. 
Clarke's transformation is used in the system and preferred as compared to dq transform because, this transformation does not loose any information even if a system imbalance occurs. Clarke transformation is an isomorphism thus there is no loss of information which means the zero sequence is considered whereas in dq transformation the zero sequence is omitted. Clarke transformation is the basis for the p-q theory that is used in the control loop of the inverter in the system for unbalance compensation. Clarke transformation converts the abc quantities in the matrix form, during the calculation of conversion of abc to two frame reference system, such that zero appears in the off diagonal terms of the matrix, making the computation easier. This transformation provides a stationary reference frame, in which compensation, balancing and elimination of harmonics are easily performed.

Table 2 Equations for Clarke and Inverse Clarke Transform

\begin{tabular}{|c|c|}
\hline CLARKE TRANSFORM & INVERSE CLARKE TRANSFORM \\
\hline $\begin{array}{ll}\text { - } & V_{0}=\frac{\left(V_{a}+V_{b}+V_{c}\right)}{\sqrt{3}} \\
\text { - } & V_{\alpha}=\left(V_{a}-\frac{V_{b}}{2}-\frac{V_{c}}{2}\right) * \sqrt{2 / 3} \\
\text { - } & V_{\beta}=\frac{\left(V_{b}-V c\right)}{\sqrt{2}} \\
\text { - } & I l_{0}=\frac{I_{a l}+I_{b l}+I_{c l}}{\sqrt{3}} \\
\text { - } & I l_{\alpha}=\left(I_{a l}-\frac{I_{b l}}{2}-\frac{I_{c l}}{2}\right) * \sqrt{\frac{2}{3}} \\
\text { - } & I l_{\beta}=\frac{I_{b l}-I_{c l}}{\sqrt{2}} \\
\text { - } & I_{0}=I l_{0} \\
\text { - } & P_{0}=V_{0} * I l_{0}(\text { Dot multiplication : * }) \\
\text { - } & P=V_{\alpha} * I l_{\alpha}+V_{\beta} * I l_{\beta} \\
\text { - } & Q=V_{\beta} * I l_{\alpha}-V_{\alpha} * I l_{\beta}\end{array}$ & $\begin{array}{ll}\text { - } & V_{0}=\frac{\left(V_{a}+V_{b}+V_{c}\right)}{\sqrt{3}} \\
\text { - } & V_{\alpha}=\left(V_{a}-\frac{V_{b}}{2}-\frac{V_{c}}{2}\right) * \sqrt{2 / 3} \\
\text { - } & V_{\beta}=\frac{\left(V_{b}-V c\right)}{\sqrt{2}} \\
\text { - } & I_{\alpha}=\frac{\left(V_{\alpha} * P+V_{\beta} * Q\right)}{V_{\alpha}^{2}+V_{\beta}^{2}} \\
\text { - } & I_{\beta}=\frac{V_{\beta} * P-V_{\alpha} * Q}{V_{\alpha}^{2}+V_{\beta}^{2}} \\
\text { - } & I_{a c}=\sqrt{\frac{2}{3}} *\left(\frac{I_{0}}{\sqrt{2}}+I_{\alpha}\right) \\
\text { - } & I_{b c}=\sqrt{\frac{2}{3}} *\left(\frac{I_{0}}{\sqrt{2}}-\frac{I_{\alpha}}{2}+\sqrt{3} * \frac{I_{\beta}}{2}\right) \\
\text { - } & I_{c c}=\sqrt{\frac{2}{3}} *\left(\left(\frac{I_{0}}{\sqrt{2}}-\frac{I_{\alpha}}{2}-I_{\beta}\right) * \sqrt{3} / 2\right)\end{array}$ \\
\hline
\end{tabular}

Where,

$V_{0}, V_{\alpha}, V_{\beta}$ are $\alpha \beta$ transformation voltage component,

$\mathrm{P}$ and $\mathrm{Q}$ is real power and reactive power respectively.

$I_{0}, I_{\alpha}, I_{\beta}$ are $\alpha \beta$ transformation current component.

$\mathrm{I}_{\mathrm{ac}}, \mathrm{I}_{\mathrm{bc}}, \mathrm{I}_{\mathrm{cc}}$ is reference current components for $\mathrm{AC}$ waveform.

\section{CONCEPT OF LOAD BALANCING}

In the proposed model, two loads are connected at the grid side for the compensation of reactive power. The control of the reactive power is defined as reactive power compensation, which leads in the improvement on the performance of AC system. In the proposed system, the reactive power compensation is performed using the load support technique. In load support technique, load balancing is performed so that the power factor of the system improves, which leads to balancing the real power at the inverter side thereby improves the regulation of voltage. Compensation of the reactive power improves the system stability by improving the power being fed to the grid and loads. As the reactive power is needed to support system voltage, consumption of more reactive power, by both load and grid, will lower the voltage. On the contrary, if there is more reactive power produced by the inverter and fed to the grid and loads and the consumption is less by the load and grid, then in the 
system there will be more reactive power which gets circulated which can lead to high system voltages. Controlling the voltage is critical for safe operation of the power system as devices are designed to operate within a specific voltage range. The loads connected in the grid side are RC loads, $5 \mathrm{~kW}$ active load power. The benefit of having inductive load (grid) and capacitive loads (RC loads) in the system, is that the inductive lagging reactive power is inverse to the polarity of leading capacitive power. The capacitive load stores, and then supplies power to the inductive load decreasing the reactive power which the source has to supply and hence power factor correction is carried out.

\section{RESULTS AND DISCUSSION}

The complete model of grid connected PV system has been developed and simulated in MATLAB/SIMULINK 2018b. The single line diagram of the PV model is shown in Figure 10. The specification of the PV module is shown in Table 3.

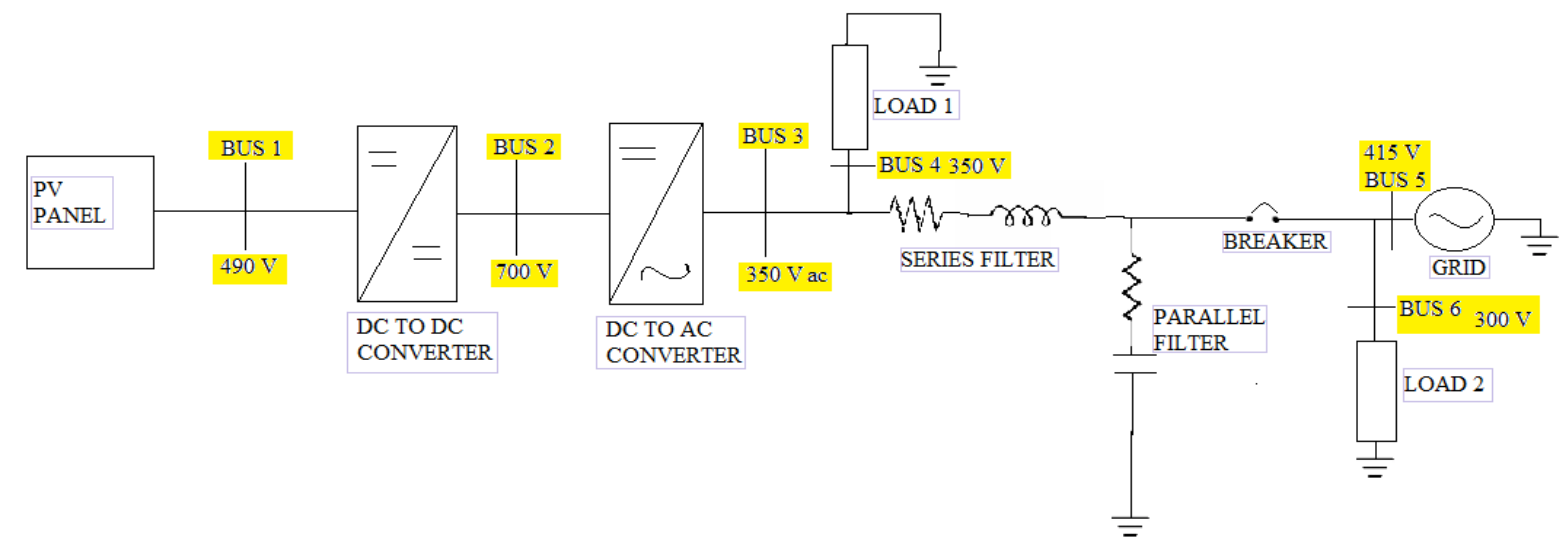

Figure 10 Single Line Diagram for Grid- tied Solar PV system

Table 3 Specification of PV System

\begin{tabular}{|l|c|}
\hline \multicolumn{1}{|c|}{ Parameters } & Specifications \\
\hline Module & 1Soltech 1STH-215-P \\
\hline Parallel String & 4 \\
\hline Series-connected module per string & 16 \\
\hline Open circuit voltage (V) & 36.3 \\
\hline Short circuit current (A) & 7.84 \\
\hline Maximum Power (W) & 213.15 \\
\hline
\end{tabular}

The system is a PV Grid connected system maintaining a power of $13.5 \mathrm{KW}$. A varying irradiance of 1000 to $500 \mathrm{~W} / \mathrm{m}^{2}$ are set at $25^{\circ} \mathrm{C}$. Two cases have been considered showing the performance of HCC and MPPT controllers in the system. Both the cases have been simulated and results are discussed below:

- Without MPPT and Hysteresis controller.

- With MPPT and Hysteresis controller

Case 1: Without MPPT and Hysteresis controller

The system is without MPPT controller and Hysteresis Current Controller. Normal pulse signal has been given in place of the controllers. For a $13.5 \mathrm{KW}$ system, the real power varies from 0 to $6 \mathrm{KW}$. So much power loss can be seen from the data. From the graph, it can clearly 
be seen that the inverter output current is distorted. The THD obtained from the system is $69.40 \%$ which violates the IEEE519_1992 regulations. The DC link voltage also exceeds the reference voltage which is $700 \mathrm{~V}$.

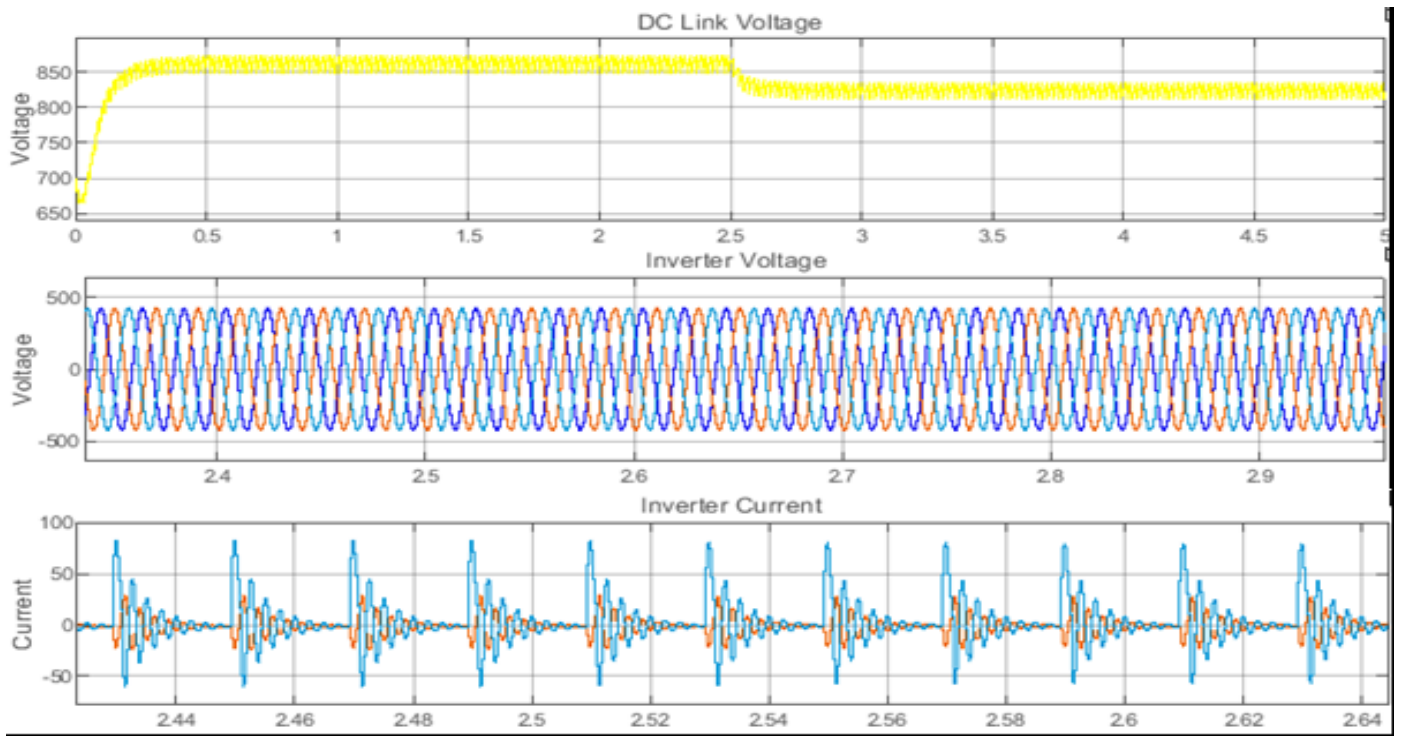

Figure 11 Inverter input voltage,Inverter output voltage,Inverter current

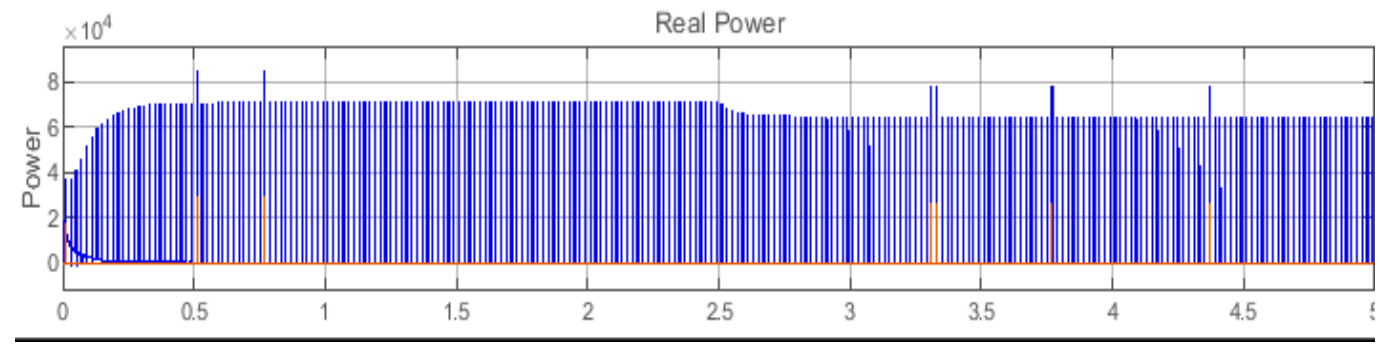

Figure 12 Real Power

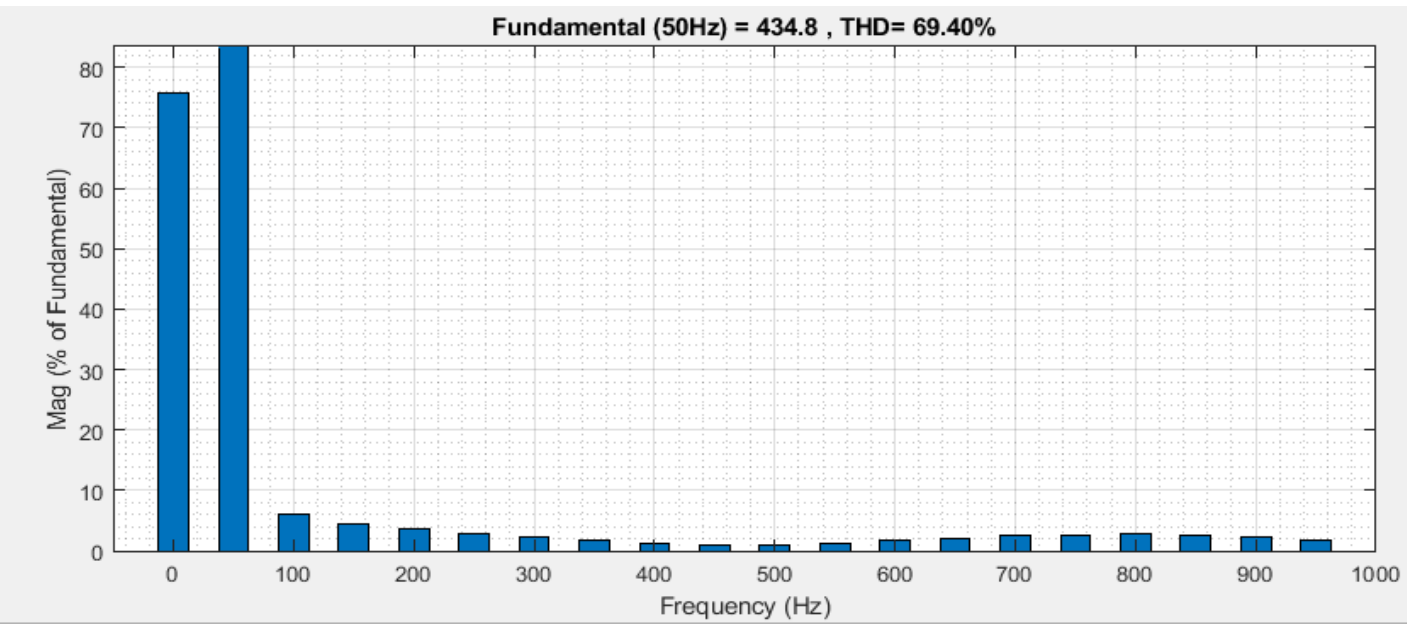

Figure 13 THD

Case 2: Proposed controller model

The system is designed with MPPT controller for the boost converter and Hysteresis Current Controller for the Inverter. From this case, it will be shown how incorporating the HCC affects the system in a better way. 
Development of Hysteresis Current Controller for Power Quality Enhancement in Grid Connected PV System
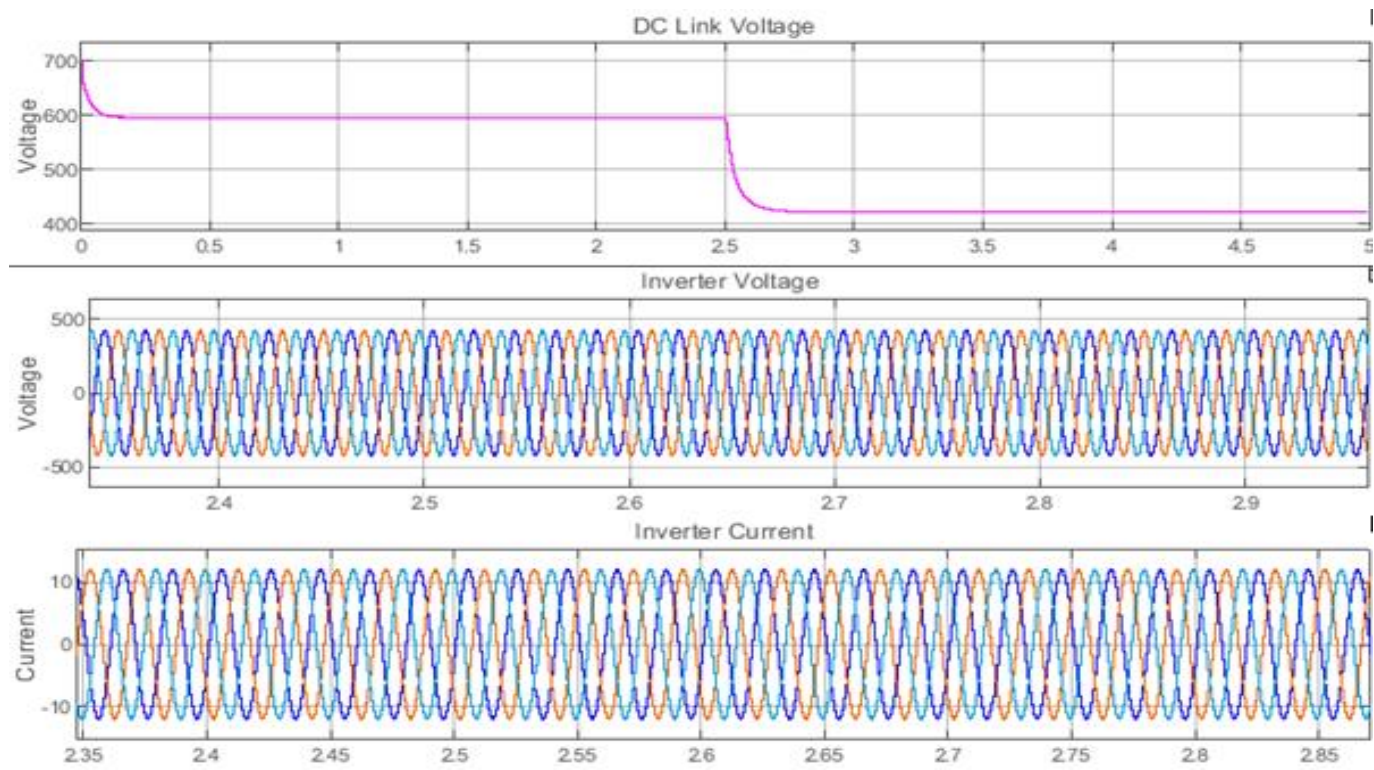

Figure 14 Inverter input voltage,Inverter output voltage,Inverter current

For a $13.5 \mathrm{KW}$ system, $12.9 \mathrm{KW}$ system is obtained at $1000 \mathrm{~W} / \mathrm{m}^{2}$ and when irradiance is decreased to $500 \mathrm{~W} / \mathrm{m}^{2}$, the power decreases to half of what was obtained at $1000 \mathrm{~W} / \mathrm{m}^{2}$. It can been seen how there is so less power loss comparing to case 1 . The DC link voltage (inverter input voltage) is maintained below the reference value $(700 \mathrm{~V})$. The inverter input current has a graph without no distortion which indicates that the system is running efficiently. The efficiency of the system is also proven with the help of THD (total harmonics distortions) which is $0.15 \%$ which is less than 5\% according to the IEEE519_1992 regulations.

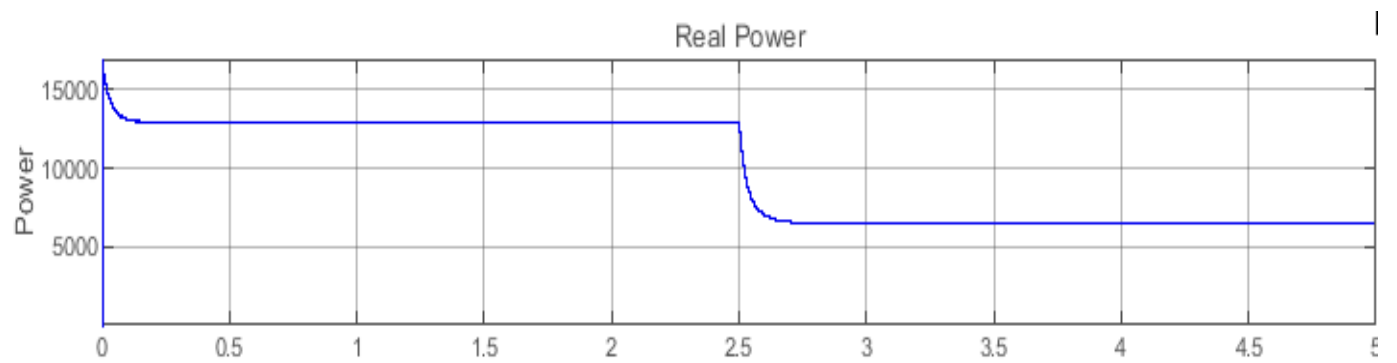

Figure 15 Real Power

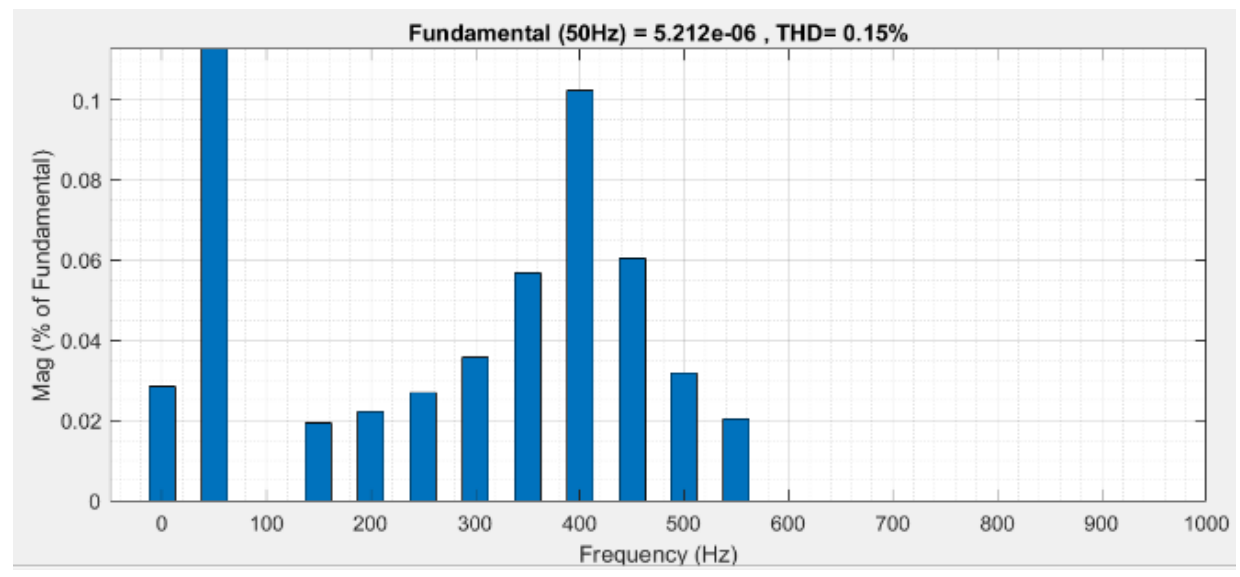

Figure 16 THD 
Dr. J Preetha Roselyn, Devraj Sen, Pratyaksha Lal, Nayanika Purkayastha and C Nithya

Table 4 Comparison of Case 1 and Case 2 at $1000 \mathrm{~W} / \mathrm{m}^{2}$ of $13.5 \mathrm{KW}$ system

\begin{tabular}{|l|c|c|}
\hline \multicolumn{1}{|c|}{ Parameters } & Case 1 & Case 2 \\
\hline PV Voltage & $560 \mathrm{~V}$ & $490 \mathrm{~V}$ \\
\hline PV Power & $6.5 \mathrm{KW}$ & $13.5 \mathrm{KW}$ \\
\hline DC link voltage & $850 \mathrm{~V}$ & $600 \mathrm{~V}$ \\
\hline Inverter voltage & $415 \mathrm{~V}$ & $415 \mathrm{~V}$ \\
\hline Inverter current & $-60 \mathrm{~A}$ to $80 \mathrm{~A}($ Distorted $)$ & $10 \mathrm{~A}$ \\
\hline Real Power & $6 \mathrm{KW}$ & $12.9 \mathrm{KW}$ \\
\hline Reactive Power & Distorted & $0 \mathrm{VAR}$ \\
\hline THD & $69.40 \%$ & $0.15 \%$ \\
\hline
\end{tabular}

\section{CONCLUSION}

By designing the Hysteresis current controller and MPPT controller, better power quality has been achieved. By using the concept of Load Balancing, the power factor of 1 is achieved. The PV array modeling, boost converter, inverter, filters, control algorithm has been studied and analyzed in detail and designed as per the system requirement. The competency of the proposed algorithm has been proven through the simulation results and validation are done with respect to following standards : IEEE 519 -2014, IEEE -5147 and IEC- 61727. The analysis concludes that with the proposed algorithm, the power quality issues has been resolved.

\section{REFERENCES}

[1] C.Shiva, (2017) Department of EEE, Mepco Schlenk Engineering College , R. Bhavani Dept. of EEE, Mepco Schlenk Engineering College, N. Rathina Prabha Dept. of EEE, Mepco Schlenk Engineering College,"Power Quality Improvement in a Grid Integrated Solar PV System", 2017 IEEE International Conference on Intelligent Techniques in Control, Optimization and Signal Processing

[2] Pekik Argo Dahono and Iskandar Krisbiantoro (2001) Department of Electrical Engineering, Bandung Institute of Technology, "A Hysteresis Current Controller For Single-Phase Full Bridge Inverters",4th IEEE International Conference on Power Electronics and Drive Systems, IEEE PEDS 2001-Indonesia,Cat. No.01TH8594

[3] S. Raja Mohamed Department of Electrical and Computer Engineering, King Faisal University, P. Aruna Jeyanthy Department of Electrical Engineering, Kalashalingham University, D. Devaraj Department of Electrical Engineering, Kalashalingham University," Hysteresis-Based Voltage And Current Control Techniques For Grid Connected Solar Photovoltaic Systems: Comparitive Study", IJECE,Volume:8,No.:5.pp2671-2681.

[4] T Raju, Dept. Electrical \& Electronics Engineering, Kamala Institute of Technology \& Science, P Ram Reddy Dept. Electrical \& Electronics Engineering, Kamala Institute of Technology \& Science, "A Novel Control Algorithm For An Adaptive Hysteresis Band Current Controlled Shunt Active Power Filter",International Refereed Journal of Engineering and Science (IRJES),ISSN :2319-1821.

[5] Chinmay D. Shukla (2019) Electrical Engineering Department, Dr. S. \& S. S. Ghandhy College of Engineering \& Technology, "Simulation Of Hysteresis Band Current Control For Grid Connected Solar Photovoltaic Inverter",Scientific Journal of Impact Factor (SJIF): 5.71,International Journal of Advance Engineering and Research Development, Volume 6, Issue 01, January.

[6] S. Raja Mohamed1, (2018), Department of Electrical and Computer Engineering, King Faisal University, Saudi Arabia, P. Aruna Jeyanthy and D. Devaraj, Department of Electrical Engineering, Kalashalingham University, India, "Hysteresis-based Voltage and 
Development of Hysteresis Current Controller for Power Quality Enhancement in Grid Connected PV System

Current Control Techniques for Grid Connected Solar Photovoltaic Systems: Comparative Study". International Journal of Electrical and Computer Engineering (IJECE) Vol. 8, No. 5, October, pp. 2671 2681 ISSN: 2088-8708.

[7] Mr. S. Sheik Mohammed College of Engineering, Dhofar University and Dr. D. Devaraj Senior Professor, (2014), Kalasalingam University, "Simulation and Analysis of Standalone Photovoltaic System with Boost Converter using MATLAB/Simulink". Conference: IEEE International Conference on Circuit, Power and Computing Technologies ICCPCT-March, DOI: 10.1109/ICCPCT.2014.7054991

[8] K.K. Pandey Asst. Prof. Dept of EXTC, S.S.J.C.O.E and Dr. P.H. Zope Associate .Prof. Dept of EXTC, S.S.B.T.C.O.E, "Analysis and Simulation of Three-phase Induction motor using Clarke's transformation", International Journal of Engineering Research \& Technology (IJERT) IJERT www.ijert.org ICONECT' 14 Conference Proceedings.

[9] Dash R, Swain SC. (2018) Effective Power quality improvement using Dynamic Activate compensation system with Renewable grid interfaced sources. Ain Shams Eng J, https://doi.org/10.1016/j.asej.2017.09.007.

[10] Performance Improvement of Grid-Integrated Solar PV System Using DNLMS Control Algorithm- Subarni Pradhan , (2019) Student Member, IEEE, Ikhlaq Hussain , Member, IEEE, Bhim Singh, Fellow, IEEE, and Bijaya Ketan Panigrahi, Senior Member, IEEE,IEEE Transactions on Industry Applications, Vol. 55, No. 1, January/Februar.

[11] A Hysteresis Current Control Technique for Electronics Convertor -Nelson A. Patel, Jaydeep C. Baria P.G. Student,(2016), Department of Electrical Engineering, BVM Engineering College, V.V.Nagar, Gujarat, Indial Associate Professor, Department of Electrical Engineering, BVM Engineering College, V.V.Nagar, Gujarat, India,International Journal of Innovative Research in Science, Engineering and Technology (A High Impact Factor, Monthly Peer Reviewed Journal) Vol. 5, Issue 2.

[12] A New Hysteresis Band Current Controller- A. Arias (I), M. G. Jape (2), E. Aldabas and J.L. Romeral (I)-Published in (2002) IEEE 33 ${ }^{\text {rd }}$ Anual IEEE Power Electronics Specialist Conference (Cat no.-02CH37289)

[13] Harmonic and Reactive Power Compensation of Grid Connected Photovoltaic System Renukadevi V Research Scholar, EEE Dept, Govt. Engg. College, Thrissur., Dr. B Jayan and Professor, (2015) EEE Dept, Govt. Engg. College, Thrissur. ELSEVIER Smart Grid Technologies, August 6-8.

[14] F.Blaabjerg, R.Teodorescu, M.Liserre, and A. V. Timbus, (2006) Overview of control and grid synchronization for distributed power generation systems, IEEE Trans. Ind. Electron., vol. 53, no. 5, pp. 1398-1409.

[15] Arul Murugan, S., Anbarasan, A., (2014). Harmonics elimination in grid connected single phase PV inverter. In: Int. Conference on Engineering Technology and Science, Tamil Nadu, India, 10-11 February 2014, (3) 1, pp. 1474-1480. 